\title{
High prevelance of human parvovirus infection in patients with malignant tumors
}

\author{
YASHA LI, YANMING DONG, JUN JIANG, YONGBO YANG, KAIYU LIU and YI LI \\ College of Life Science, Central China Normal University, Wuhan 430072, P.R. China
}

Received October 12, 2011; Accepted December 21, 2011

DOI: 10.3892/ol.2012.548

\begin{abstract}
It is well known that the immunity of patients with malignant tumors decreases significantly. An increased parvovirus B19 (B19) infection rate has been observed in immunocompromised hosts. However, only a small amount of literature regarding the risk of human parvovirus infection in patients with malignant tumors is available. To evaluate the correlation of human parvovirus infection with malignant tumors, 288 serum samples from patients with malignant tumors were screened for B19 DNA by nested-PCR. The serum samples, 156 of which were from known clinicopathological cancer patients, were subjected to analysis of the seropositive rate of human bocavirus $(\mathrm{HBoV})$, hepatitis $\mathrm{B}$ virus $(\mathrm{HBV})$ and transfusion transmitted virus (TTV) by PCR. A total of 800 normal population sera and 941 aspirate samples from children with respiratory tract infections were used as controls for the detection of B19 and $\mathrm{HBoV}$, respectively. Pairwise comparison between cancerous serum and control samples, and the correlation between parvovirus infection and clinicopathological variables, including gender and cancer type, were evaluated using the $\chi 2$ test, Fisher's exact test or the t-test. $\mathrm{P}<0.05$ was considered to indicate a statistically significant difference. The overall prevalence of B19 DNA in cancer patients was $50.69 \%$ (146/288), which was significantly higher than that of the healthy controls with $4.5 \%(36 / 800)(\chi 2$ test, $\mathrm{P}<0.0001)$. Similar results were obtained for $\mathrm{HBoV}$ with a $39.74 \%(62 / 156)$ prevalence in cancer patients. However, the infection prevalence of $\mathrm{HBV}$ and TTV in the cancer patients was $5.13(8 / 156)$ and $6.41 \%(10 / 156)$, respectively $(\mathrm{P}<0.0001)$, which was much less than that of $\mathrm{B} 19$ and HBoV. These results revealed that a high risk of $\mathrm{B} 19$ and $\mathrm{HBoV}$ infection occurred
\end{abstract}

Correspondence to: Professor Kaiyu Liu or Professor $\mathrm{Yi} \mathrm{Li}$, College of Life Science, Central China Normal University, Wuhan 430072, P.R. China

E-mail: liukaiyu@mail.ccnu.edu.cn

E-mail: liyi@mail.ccnu.edu.cn

Key words: human parvovirus B19, human bocavirus, malignant tumors, nested-PCR, seroprevalence in cancer patients, and a potential correlation exists between parvovirus infection and occurrence of malignant tumors.

\section{Introduction}

Human parvovirus B19 (B19) is a small DNA virus with a single-stranded linear genome which encodes one non-structural protein, NS-1, and two viral capsid proteins, VP1 (83 kDa) and VP2 (58 kDa) (1). B19 is the aetiological agent of a number of diseases (2) and infection wi th B19 is a global concern. In immunologically healthy hosts, B19 may cause a number of acute, generally self-limiting diseases, notably, fifth disease or erythema infectiosum in children, acute polyarthritis in adults, and aplastic crisis in patients with chronic hemolytic anemia, including sickle cell anemia or hereditary spherocytosis (3-6). In pregnant women, B19 infection may result in the lysis of nucleated fetal red blood cells, hydrops fetalis, and subsequent spontaneous abortion and fetal mortality (7). B19 has also been found to be associated with glomerulonephritis, vasculitis, peripheral neuropathies, myocarditis and fulminant hepatic failure (8). In immunocompromised hosts, B19 infection may persist and lead to chronic anemia, red cell aplasia, and less frequently, thrombo-cytopenia, neutropenia and pancytopenia (9-11). However, only a small amount of literature regarding the involvement of B19 in malignant tumors is available. In this study, we examined whether cancer patients have a higher risk of B19 infection, in order to further understand the effect of B19 infection on the pathogenesis of cancer patients.

Human bocavirus (HBoV) is a recently identified parvovirus associated with respiratory and gastrointestinal diseases in humans. It was first identified in children with lower respiratory tract infections (LRTIs) in October 2005 (12). Since then, the detection of $\mathrm{HBoV}$ in acute respiratory illness has been reported worldwide, with prevalence rates between 1.5 and $19 \%$ (13-15). It was subsequently detected in serum (16-17), fecal (18-19) and urine samples (20). HBoV detection was significantly higher in patients with symptoms of respiratory tract infections or gastroenteritis than in asymptomatic individuals $(14,16,21-23)$. Findings of a recent study suggest that acute infection of $\mathrm{HBoV}$ causes systemic infection, induces immune responses and is often associated with coinfection (24). At present, the biological features of $\mathrm{HBoV}$ and the significance of human disease by this virus remain unknown. Since a second parvovirus causes human disease following 
Table I. Primers used in viral genome amplification.

\begin{tabular}{|c|c|c|c|c|}
\hline Virus & $\begin{array}{l}\text { Amplification } \\
\text { region }\end{array}$ & Forward primer & Reverse primer & $\begin{array}{l}\text { Size } \\
\text { (bp) }\end{array}$ \\
\hline \multirow[t]{2}{*}{ B19 } & \multirow[t]{2}{*}{ NS } & Outer 5'-TCACCATATTCTTGGGAACAAGA-3' & 5'-CTGCTTTCACTGAGTTCTTC-3' & \\
\hline & & Inner 5'-AATACACTGTGGTTTTATGGGCCG-3' & 5'-CCATTGCTGGTTATAACCACAGGT-3' & \\
\hline $\mathrm{HBoV}$ & NP1 & 5'-TATCGTCTTGCACTGCTTCG-3' & 5'-AGAGTAGGCGTGATCATGTAA- 3' & \\
\hline \multirow[t]{2}{*}{ HBV } & \multirow[t]{2}{*}{$\mathrm{S}$} & Outer 5'-TCACCATATTCTTGGGAACAAGA-3' & 5'-CGAACCACTGAACAAATGGC-3' & \\
\hline & & Inner 5'-CCCATATCGTCAATCTTCTCGAGGA-3' & 5'-GTAGTTGATGTTCCTGGAAGTAGAGG-3' & \\
\hline \multirow[t]{2}{*}{ TTV } & \multirow[t]{2}{*}{ ORF1 } & Outer 5'-GCAGCAGCATATGGATATGT-3' & 5'-TGACTGTGCTAAAGCCTCTA-3' & \\
\hline & & Inner 5'-CATACACATGAATGCCAGGC-3' & 5'-TGACTGTGCTAAAGCCTCTA-3' & \\
\hline
\end{tabular}

B19, parvovirus 19; HBoV, human bocavirus; HBV, hepatits B virus; TTV, transfusion transmitted virus; NS, non-structural protein; NP1, non-structural protein; $\mathrm{S}$, gene $\mathrm{S}$ region; ORF1, open reading frame 1.

B19, the infection incidence of this virus in cancer patients also evokes our interest.

\section{Materials and methods}

Patients and specimens. Serum samples of 288 cancer patients, 156 of which were from known clinicopathological cancer patients, were collected from the Second Hospital of Wuhan Iron and Steel Company (WISCO). To evaluate whether hepatitis B virus (HBV) infection is associated with B19 infection, 113 blood samples from patients with hepatitis were also obtained from the same hospital. A total of 800 serum samples from normal blood donors, without known ages and genders, were randomly selected at the Sixth Hospital of Wuhan and 941 aspirate samples from children with respiratory tract infections were collected at the Hubei Maternal and Child Health Hospital in Wuhan. Both served as controls. All the nucleic acid extracted from the serum and sputum samples were stored at $-80^{\circ} \mathrm{C}$ upon arrival in the laboratory until it was tested for parvovirus DNA. The study was approved by the academic committee of the Central China Normal University and the analysis of patients' blood samples was agreed by the Second Hospital of Wuhan Iron and Steel Company (WISCO).

Primer design. The primers used to amplify the DNA of the B19, HBoV, HBV and transfusion transmitted virus (TTV) were designed (Table I) based on the most conserved sequences encoding the non-structural protein (NS) of parvovirus B19 (GenBank accession number, AY386330), the non-structural protein (NP1) of parvovirus HBoV (GU139423), the S gene region of HBV and the ORF1 region of TTV (AB008394), and were synthesized by Genscript Genetech Co. Ltd, China. The virus DNA was detected using nested-PCR with 2 pairs of primers, except for $\mathrm{HBoV}$, which was detected by only one pair of primers.

DNA extraction, nested-PCR and sequencing. Total nucleic acid was extracted from each specimen by the Roche High Pure Viral Nucleic Acid kit (Roche Diagnostics, Mannheim, Germany), according to the manufacturer's instructions. The DNA extracts were stored at $-80^{\circ} \mathrm{C}$ prior to PCR analysis.
The extracted DNA $(2.5 \mu \mathrm{l})$ was added to the PCR mixture containing $2.5 \mu \mathrm{l}$ of $10 \mathrm{X}$ reaction buffer (Tiangen Biotech, Beijing Co. Ltd, China), $200 \mu \mathrm{M}$ of each dATP, dCTP, dGTP and dTTP, $12.5 \mathrm{pmol}$ of each primer and 1.25 units of Taq polymerase (Tiangen Biotech). The nested-PCR of B19 was performed under the following conditions: denaturation at $94^{\circ} \mathrm{C}$ for $4 \mathrm{~min}, 30$ cycles of $94^{\circ} \mathrm{C}$ for $30 \mathrm{sec}$, annealing at $56^{\circ} \mathrm{C}$ for $30 \mathrm{sec}$ and $72^{\circ} \mathrm{C}$ for $1 \mathrm{~min}$ and elongation at $72^{\circ} \mathrm{C}$ for $10 \mathrm{~min}$. Following the first amplification, the second PCR was performed under the same conditions as described above, except that the annealing temperature was reset at $58^{\circ} \mathrm{C}$, and $0.5 \mu 1$ of the first PCR product was added to the nested-PCR mixture using the specific primers. The amplification of $\mathrm{HBoV}$ included a step at $94^{\circ} \mathrm{C}$ for $3 \mathrm{~min}$, followed by 35 cycles of $30 \mathrm{sec}$ at $94^{\circ} \mathrm{C}, 30 \mathrm{sec}$ at $55^{\circ} \mathrm{C}$ and $1 \mathrm{~min}$ at $72^{\circ} \mathrm{C}$. The reactions were carried out using a thermocycler 5332 (Eppendorf, Germany).

Samples $(5 \mu 1)$ of second-round PCR products were analyzed by electrophoresis on a $2 \%$ agarose gel and then visualized by UV light following ethidium bromide staining. The plasmids pB19-4244 (kindly provided by Professor Tijjsen, Canada) and pWHL-1 (genomic clones of HBoV constructed previously in our lab) were used as the positive controls for B19 and HBoV, respectively. A number of precautions were taken to avoid contamination of the samples with PCR products. The reaction reagents were prepared with pipettes and containers which had never come into contact with amplified products or with positive samples. Reactions containing all the PCR reagents and sterile distilled water, instead of the DNA samples from the specimens, were used as negative controls.

The amplified DNA fragments of the expected sizes were gel purified, cloned into the vector $\mathrm{pCR}^{\circledR} 2.1-\mathrm{TOPO}^{\circledR}$ (Invitrogen Life Technologies, Carlsbad, CA, USA) and transformed into chemically competent $E$. coli DH5 $\alpha$. A single colony was cultured and the corresponding plasmid DNA was sequenced using standard techniques.

Statistical analysis. A pairwise comparison between cancerous serum and control samples, and the correlation between parvovirus infection and clinicopathological variables, including gender and cancer type, was evaluated by the $\chi 2$ test, Fisher's exact test or the t-test. $\mathrm{P}<0.05$ was considered to indicate a 
A

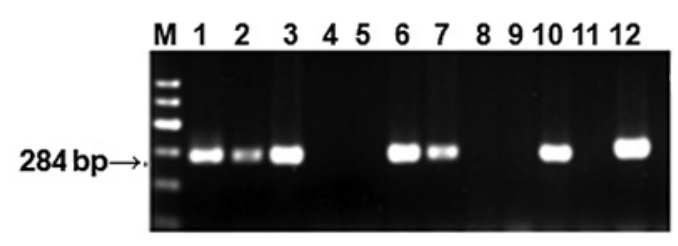

C

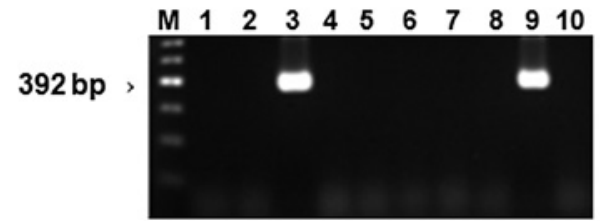

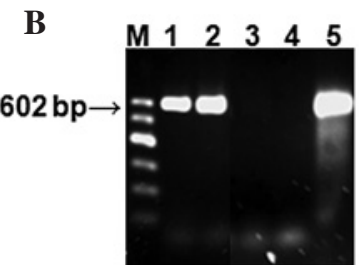

D

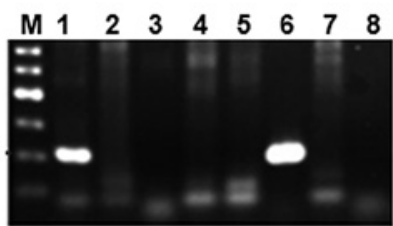

Figure 1. Analysis of PCR products by agarose gel electrophoresis. M, Marker. (A) B19 DNA was amplified using nested-PCR as described in Materials and methods. Lanes 1, 2, 3, 6, 7 and 10, six seropositive samples; lanes 4, 5, 8 and 9, four seronegative samples; lane 11, negative control; lane 12, positive control. (B) HBoV DNA amplified using PCR. Lanes 1 and 2, seropositive samples; lane 3, seronegative sample; lane 4, negative control; lane 5, positive control. (C) HBV DNA amplified using nested-PCR. Lanes 3 and 9, seropositive samples; lane 10, negative control. (D) TTV DNA was amplified using nestedPCR. Lanes 1 and 6, seropositive samples; lane 8, negative control. B19, parvovirus 19; HBoV, human bocavirus; HBV, hepatits B virus; TTV, transfusion transmitted virus.

Table II. Seroprevalence of B19 DNA detected by nPCR in cancer patients and control groups.

\begin{tabular}{|c|c|c|c|c|c|c|c|c|c|}
\hline \multirow[b]{2}{*}{ Group } & \multicolumn{3}{|c|}{$\begin{array}{l}\text { Cancer } \\
\text { serum }\end{array}$} & \multirow{2}{*}{$\begin{array}{c}\begin{array}{c}\text { Normal } \\
\text { serum }\end{array} \\
\mathrm{D} \\
\text { B19 }\end{array}$} & \multirow{2}{*}{$\begin{array}{c}\begin{array}{c}\text { Hepatitis } \\
\text { serum }\end{array} \\
\text { E } \\
\text { B19 }\end{array}$} & \multicolumn{4}{|c|}{$\mathrm{P}$-value ${ }^{\mathrm{a}}$} \\
\hline & $\begin{array}{l}\text { A } \\
\text { B19 }\end{array}$ & $\begin{array}{c}\text { B } \\
\mathrm{HBV}\end{array}$ & $\begin{array}{c}\mathrm{C} \\
\text { TTV }\end{array}$ & & & A vs. B & A vs. C & A vs. D & A vs. E \\
\hline $\begin{array}{l}\text { Positive } \\
\text { rate } \% \\
\text { (n) }\end{array}$ & $\begin{array}{l}42.3 \\
(66 / 156)\end{array}$ & $\begin{array}{c}5.13 \\
(8 / 156)\end{array}$ & $\begin{array}{c}6.41 \\
(10 / 156)\end{array}$ & $\begin{array}{c}4.5 \\
(36 / 800)\end{array}$ & $\begin{array}{c}15.9 \\
(18 / 113)\end{array}$ & 0.0001 & 0.0001 & 0.0001 & 0.0001 \\
\hline
\end{tabular}

${ }^{\mathrm{a}} \chi^{2}$ test. ${ }^{\mathrm{b}}$ Reported as the percentage (number) of patients, unless otherwise indicated. nPCR, nested PCR; B19, parvovirus 19; HBoV, human bocavirus; HBV, hepatits B virus; TTV, transfusion transmitted virus.

statistically significant difference. Statistical analyses were performed using SAS9.2 software (SAS institute Inc, Cary, NC, USA).

\section{Results}

High prevalence of $\mathrm{B} 19$ and $\mathrm{HBoV}$ infection in tumor patients. To determine the prevalence of B19 infection in cancer patients, a total of 288 cancer patients were enrolled in this study between August and November 2010 and B19 DNA was examined using nested-PCR (Fig. 1A), as described in the Materials and methods. The results indicated that the overall prevalence of B19 DNA in adult cancer patients was $50.69 \%$ (146/288), which was significantly higher than that of the healthy controls with $4.5 \%(36 / 800)$ ( $\chi 2$ test, $\mathrm{P}<0.0001)$. Among these 288 cancer patients, 156 patients with pertinent clinicopathological features were subjected to further examination of the seropositive rate of $\mathrm{HBoV}, \mathrm{HBV}$ and TTV in their serum (Fig. 1B-D). Our data revealed that the prevalence percentage of $\mathrm{HBoV}$ infection in cancer patients was $39.74 \%$ (62/156), ranked second as compared to the total analysis, whereas the infection prevalence of $\mathrm{HBoV}$ from 941 children with respiratory tract infections was $3.51 \%$ (33/941), which was significantly less (Table III) than that in the cancer patients.

Subsequently, 113 serum samples from hepatitis patients without cancer were examined for B19 and HBoV DNA using PCR assay as the control. The prevalence percentages of B19 and $\mathrm{HBoV}$ infection in hepatitis B patients were $15.9(18 / 113)$ and $7.08 \%$ (8/113), respectively; both are significantly less than that of the cancer patients with 42.3 (66/156) and $39.7 \%$ (62/156) (Tables II and III). These results suggest that a high prevalence of parvovirus infection commonly occurred in cancer patients, and a possible novel link may exist between parvovirus infection and malignant tumors.

We then evaluated whether or not the cancer patients are also the targets of other viruses, by using HBV and TTV as controls. Our results revealed that the infection prevalence for HBV and TTV were 5.13 (8/156) and 6.41\% (10/156), respectively (Tables II and III), demonstrating that the decreased immunity of the patients with malignant tumors is not the only reason for high parvovirus infection incidence. 
Table III. Seroprevalence of HBoV DNA detected by nPCR in cancer patients and control groups.

\begin{tabular}{|c|c|c|c|c|c|c|c|c|c|}
\hline \multirow[b]{2}{*}{ Group } & \multicolumn{3}{|c|}{$\begin{array}{l}\text { Cancer } \\
\text { serum }\end{array}$} & \multirow{2}{*}{$\begin{array}{c}\begin{array}{c}\text { Throat } \\
\text { swab }\end{array} \\
\text { D } \\
\mathrm{HBoV}\end{array}$} & \multirow{2}{*}{ 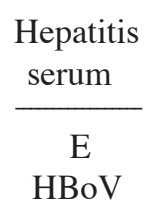 } & \multicolumn{4}{|c|}{ P-value ${ }^{a}$} \\
\hline & $\begin{array}{c}\text { A } \\
\mathrm{HBoV}\end{array}$ & $\begin{array}{c}\text { B } \\
\mathrm{HBV}\end{array}$ & $\begin{array}{c}\mathrm{C} \\
\text { TTV }\end{array}$ & & & A vs. B & A vs. $\mathrm{C}$ & A vs. D & A vs. E \\
\hline $\begin{array}{l}\text { Positive } \\
\text { rate \% } \\
\text { (n) }\end{array}$ & $\begin{array}{l}36.7 \\
(62 / 156)\end{array}$ & $\begin{array}{c}5.13 \\
(8 / 156)\end{array}$ & $\begin{array}{c}6.41 \\
(10 / 156)\end{array}$ & $\begin{array}{c}3.51 \\
(33 / 941)\end{array}$ & $\begin{array}{c}7.08 \\
(8 / 113)\end{array}$ & 0.0001 & 0.0001 & 0.0001 & 0.0001 \\
\hline
\end{tabular}

${ }^{a} \chi^{2}$ test. ${ }^{b}$ Reported as the percentage (number) of patients, unless otherwise indicated. nPCR, nested PCR; B19, parvovirus 19; HBoV, human bocavirus; HBV, hepatits B virus; TTV, transfusion transmitted virus.

Table IV. Parvovirus B19 infection and clinicopathological variables.

\begin{tabular}{lccr}
\hline & \multicolumn{2}{c}{ B19 DNA $^{\mathrm{a}}$} \\
\cline { 2 - 3 } Variables & Positive (\%) & Negative (\%) & P-value $^{\text {b }}$ \\
\hline Total patient sample & $66(42.3)$ & $90(57.7)$ & 0.8697 \\
Male & $47(42.7)$ & $63(57.3)$ & \\
Female & $19(41.3)$ & $27(58.7)$ & 0.0095 \\
Cancer category & & & 0.3125 \\
Lung & $30(56.6)$ & $23(43.4)$ & 0.2334 \\
Breast & $6(31.6)$ & $13(68.4)$ & 0.4978 \\
Stomach & $9(56.2)$ & $7(43.8)$ & 0.7694 \\
Liver & $5(31.3)$ & $11(68.7)$ & 0.2542 \\
Prostate & $6(46.2)$ & $7(53.8)$ & 0.3969 \\
Intestinal & $5(29.4)$ & $12(70.6)$ & 0.1217 \\
Renal & $1(20.0)$ & $4(80.0)$ & $13(76.5)$ \\
Other malignancies & & & \\
\hline
\end{tabular}

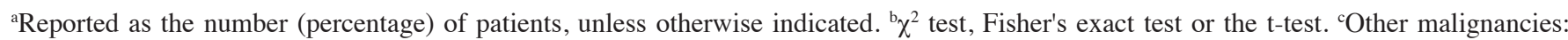
lymphoma, nasopharyngeal cancer, hepatocellular carcinoma, germ cell tumor, esophageal cancer, uterus carcinoma, pancreatic cancer, cancer of the larynx, brain metastases cancer, bladder carcinoma, mediastinal mass and endometrial cancer.

Clinical parameters of the cancer patients. Analysis of the detection results for $\mathrm{B} 19, \mathrm{HBoV}, \mathrm{HBV}$ and TTV from the 156 cancer patients, ranging from 26 to 85 years old (mean, $63.38 \pm 10.56 ; 110$ male and 46 female), indicated that the infection rate in all age groups of patients was higher for B19 and $\mathrm{HBoV}$ (Table II and III). The infection prevalence of B19 increased slightly in the older age groups, but no such trend was observed for $\mathrm{HBoV}$ infection.

Comparison of parvovirus infection in different cancer categories. A further comparison of the seropositive rate of parvovirus B19 DNA in different cancer categories revealed a markedly higher seroprevalence in the lung and stomach cancer groups (Table IV). No significant difference in B19 seroprevalence was observed among breast, liver and prostate cancer patients. The consequence of high levels of infection in lung and stomach cancer patients is unknown and more samples may be required to confirm the results.
The highest level of HBoV seroprevalence was detected in prostate cancer patients with $61.54 \%$, although there is no statistical significance due to the small sample size (Table V). The HBoV occurrence was ranked second highest in the stomach cancer patients with a 50\% (8 of 16) seropositivity rate, followed by colon cancer with 47.1 , breast cancer with 42.11 and lung cancer with $35.85 \%$. The liver cancer and other malignancies, including lymphoma, nasopharyngeal cancer, hepatocellular carcinoma, germ cell tumor, uterus carcinoma, cancer of the larynx, brain metastases, bladder carcinoma, mediastinal mass, endometrial, esophageal and pancreatic cancers, had a relatively lower HBoV seroprevalence of 18.75 and $29.41 \%$, respectively.

\section{Discussion}

The initial objective of this study was to determine the correlation between parvovirus 4 occurrence and coinfection 
Table V. Parvovirus HBoV infection and clinicopathological variables.

\begin{tabular}{|c|c|c|c|}
\hline \multirow[b]{2}{*}{ Variables } & \multicolumn{2}{|c|}{$\mathrm{HBoV}_{\mathrm{DNA}}{ }^{\mathrm{a}}$} & \multirow[b]{2}{*}{ P-value } \\
\hline & Positive (\%) & Negative $(\%)$ & \\
\hline Total patient sample & $62(39.7)$ & $94(60.3)$ & \\
\hline Male & $42(38.2)$ & $68(61.8)$ & 0.5376 \\
\hline Female & $20(43.5)$ & $26(56.5)$ & \\
\hline \multicolumn{4}{|l|}{ Cancer category } \\
\hline Lung & $19(35.8)$ & $34(64.2)$ & 0.4756 \\
\hline Breast & $8(42.1)$ & $11(57.9)$ & 0.8224 \\
\hline Stomach & $8(50.0)$ & $8(50.0)$ & 0.3762 \\
\hline Liver & $3(18.8)$ & $13(81.2)$ & 0.1042 \\
\hline Prostate & $8(61.5)$ & $5(38.5)$ & 0.7694 \\
\hline Intestinal & $8(47.1)$ & $9(52.9)$ & 0.5138 \\
\hline Renal & $0(00.0)$ & $5(100.0)$ & 0.1577 \\
\hline Other malignancies ${ }^{c}$ & $5(29.4)$ & $12(70.6)$ & 0.5138 \\
\hline
\end{tabular}

${ }^{a}$ Reported as the number (percentage) of patients, unless otherwise indicated. ${ }^{b} \chi^{2}$ test, Fisher's exact test or the t-test. ${ }^{c}$ Other malignancies: lymphoma, nasopharyngeal cancer, hepatocellular carcinoma, germ cell tumor, and esophageal cancer, uterus carcinoma, pancreatic cancer, cancer of the larynx, brain metastases cancer, bladder carcinoma, mediastinal mass and endometrial cancer.

with other parvoviruses. Therefore, sera randomly selected from 132 cancer and 83 hepatitis B patients, without known clinical features, were screened for several viruses, including parvovirus 4 (PARV4), human bocavirus (HBoV), parvovirus $\mathrm{B} 19$ and hepatitis B virus (HBV) using PCR. We found that the seroprevalence of $\mathrm{B} 19$ and $\mathrm{HBoV}$ in cancer patients was extremely high compared to the normal population and HBV patients (data not shown).

We further collected sera from 156 cancer and 30 hepatitis patients with pertinent clinicopathological parameters, and examined the DNA of B19, HBoV, HBV and TTV in the sera of these cancer and hepatitis patients, and obtained the same results. As TTV and HBV are widely distributed throughout the world, with characteristics of latent infection and positivity rates for the two viruses at below $20 \%$ in healthy populations, similar to B19 occurrence, we selected these two viruses as the controls. Overall prevalence of B19 DNA in adult cancer patients and healthy blood donors was found to be 46.0 and $4.5 \%$, respectively $(\mathrm{P}<0.0001)$, whereas the infection rates of $\mathrm{HBoV}$ in cancer patients and children with respiratory tract infections were 39.7 and $3.51 \%$, respectively $(\mathrm{P}<0.0001)$. The parvovirus $\mathrm{B} 19$ and $\mathrm{HBoV}$ viral load levels in the diagnostic serum samples revealed a correlation between malignant tumors and parvovirus DNA, suggesting that cancer patients are at high risk of parvovirus B19 and $\mathrm{HBoV}$ infection. This is the first study describing the high prevalence of parvovirus $\mathrm{B} 19$ and $\mathrm{HBoV}$ infection in cancer patients, especially the high prevalence of B19 infection in lung cancer patients. Since B19 and HBoV infections usually present with non-specific symptoms and are easily overlooked, a high degree of suspicion and a careful search for clinical evidence of infection are required.

A host with a compromised immune system is particularly at risk of B19 infection, including individuals with AIDS, cancer patients who are receiving chemotherapy and transplant patients on immunosuppressive drugs (25). These individuals are usually unable to produce neutralizing antibodies to clear the virus and this can lead to persistent infection, resulting in anemia (25-26). Therefore, it is comprehensible that the B19 infection rate in cancer groups is higher than that in the normal population in this study. However, the low infection prevalence of HBV and TTV in the same cancer sera suggested that the damaged immunity of the patients with malignant tumors is not the sole reason for explaining the high parvovirus infection incidence.

Wang et al (24) reported that acute infection of $\mathrm{HBoV}$ causes systemic infection and induces immune responses. In the present study, we found that although $\mathrm{HBoV}$ commonly exists in the serum of cancer patients, 50\% (31/62) of the incidence is coinfection with other viruses (28 of which are with B19). Thus, whether $\mathrm{HBoV}$ is a major cause of malignant tumors remains to be determined. However, it is advisable for cancer patients to avoid contact with individuals who are infected with B19 and HBoV.

Additionally, the reasons for only lung cancer patients being more susceptible to B19 infection remain to be defined. We suspect that nosocomial infection by B19 may be significant in this scenario (27). Lung cancer is one of the most common malignant tumors in China, and its incidence ranks first compared to all types of tumors. Therefore, lung cancer patients are more often hospitalized to receive chemotherapy and may have an increased risk of nosocomial infection with B19 due to blood transmission and person-to-person contact. In this study, sera were collected from cancer patients in the Second Hospital of Wuhan Iron and Steel Company (WISCO). The patients mostly work in or reside in the area near the factory. Long-term air pollution may be the main cause of the large numbers of lung cancers. Another possible factor is that we obtained the majority of the serum samples from the 
lung cancer patients and an insufficient sample size is the main reason for the seroprevalence of B19 infection being of statistical significance in the analysis.

In conclusion, human parvovirus B19 and HBoV DNA commonly occur in the serum of cancer patients, and a possible novel link may exist between parvovirus infection and malignant tumors. Early diagnosis of this easily over-looked infection is crucial and can only be achieved by a high degree of clinical suspicion. Further studies are required to delineate an epidemiological investigation of the correlation between malignant tumors and human parvovirus infection.

\section{Acknowledgements}

We are grateful to all the patients who participated in this study. This study was supported by the National Natural Science Foundation of P.R. China (30670081).

\section{References}

1. Ozawa K and Young NS: Characterization of capsid and noncapsid proteins of B19 parvovirus propagated in human erythroid bone marrow culture. J Virol 61: 2627-2630, 1987.

2. Bultmann BD, Klingel K, Sotlar K, et al: Parvovirus B19: a pathogen responsible for more than hematologic disorders. Virchows Arch 442: 8-17, 2003.

3. Anderson MJ, Higgins PG, Davis LR, et al: Experimental parvoviral infection in humans. J Infect Dis 152: 257-265, 1985.

4. Kelleher JF, Luban NL, Mortimer PP and Kamimura T: Human serum parvovirus: a specific cause of aplastic crisis in children with hereditary spherocytosis. J Pediatr 102: 720-722, 1983.

5. Pattison JR, Jones SE, Hodgson J, et al: Parvovirus infections and hypoplastic crisis in sickle-cell anemia. Lancet 317: 664-665, 1981.

6. Reid DM, Reid TM, Brown T, et al: Human parvovirus associated arthritis: a clinical and laboratory description. Lancet 325 422-425, 1985

7. Kinney JS, Anderson LJ, Farrar J, et al: Risk of adverse outcomes of pregnancy after human parvovirus B infection. J Infect Dis 7 : 663-667, 1988

8. Torok TJ: Unusual clinical manifestations reported in patients with parvovirus B19 infection. Monogr 20: 61-92, 1997.

9. Ahsan N, Holman MJ, Gocke CD, et al: Pure red cell aplasia due to parvovirus B19 infection in solid organ transplantation. Clin Transpl 11: 265-270, 1997.

10. Chernak E, Dubin G, Henry D, et al: Infection due to parvovirus B19 in patients infected with human immunodeficiency virus. Clin Infect Dis 20: 170-173, 1995.
11. Kurtzman GJ, Ozawa K, Cohen B, et al: Chronic bone marrow failure due to persistent B19 parvovirus infection. N Engl J Med 317: 287-294, 1987.

12. Allander T, Tammi MT, Eriksson M, et al: Cloning of a human parvovirus by molecular sereening of respiratory tract samples. Proc Natl Acad Sci USA 102: 12891-12898, 2005.

13. Allander T: Human bocavirus. J Clin Virol 41: 29-33, 2008.

14. Lindner J, Karalar L, Schimanski S, et al: Clinical and epidemiological aspects of human bocavirus infection. J Clin Virol 43: 391-395, 2008.

15. Tozer SJ, Lambert SB, Whiley DM, et al: Detection of human bocavirus in respiratory, fecal, and blood samples by real-time PCR. J Med Virol 81: 488-493, 2009.

16. Fry AM, Lu X, Chittaganpitch M, et al: Human bocavirus: a novel parvovirus epidemiologically associated with pneumonia requiring hospitalization in Thailand. J Infect Dis 195: 1038-1045, 2007.

17. Allander T, Jartti T, Gupta S, et al: Human bocavirus and acute wheezing in children. Clin Infect Dis 44: 904-910, 2007.

18. Neske F, Blessing K, Tollmann F, et al: Real-time PCR for diagnosis of human bocavirus infections and phylogenetic analysis. J Clin Microbiol 45: 2116-2122, 2007.

19. Vicente D, Cilla G, Montes M, et al: Human bocavirus, a respiratory and enteric virus. Emerg Infect Dis 13: 636-637, 2007.

20. Pozo F, García-García ML, Calvo C, et al: High incidence of human bocavirus infection in children in Spain. J Clin Virol 40: 224-228, 2007.

21. Kesebir D, Vazquez M, Weibel C, et al: Human bocavirus infection in young children in the United States: molecular epidemiological profile and clinical characteristics of a newly emerging respiratory virus. J Infect Dis 194: 1276-1282, 2006.

22. Maggi F, Andreoli E, Pifferi M, et al: Human bocavirus in Italian patients with respiratory diseases. J Clin Virol 38: 321-325, 2007.

23. García-García ML, Calvo C, Pozo F, et al: Human bocavirus detection in nasopharyngeal aspirates of children without clinical symptoms of respiratory infection. Pediatr Infect Dis J 27: 358-360, 2008.

24. Wang K, Wang W, Yan H, et al: Correlation between bocavirus infection and humoral response, and co-infection with other respiratory viruses in children with acute respiratory infection. J Clin Virol 47: 148-155, 2010.

25. Young NS: Parvoviruses. In: Fields Virology. Knipe DM and Howley PM (eds). 3rd edition. Lippincott, Williams and Wilkins, Philadelphia, USA. pp2199-2220, 1996.

26. Kurtzman GJ, Cohen BJ, Field AM, et al: Immune response to B19 parvovirus and an antibody defect in persistent viral infection. J Clin Invest 84: 1114-1123, 1989.

27. Sung HK, Lin LI, Chang C J, et al: Increased risk of parvovirus $\mathrm{B} 19$ infection in young adult cancer patients receiving multiple courses of chemotherapy. J Clin Microbiol 40: 3909-3912, 2002. 